\title{
Cross-cultural adaptation of the Spence Children's Anxiety Scale in Malaysia
}

\author{
Adaptação cultural da Escala de Ansiedade Infantil de Spence para a Malásia
}

Atefeh Ahmadi, ${ }^{1}$ Mohamed Sharif Mustaffa, ${ }^{2}$ AliAkbar Haghdoost, ${ }^{3}$ Aqeel Khan, ${ }^{1}$ Adibah Abdul Latif ${ }^{1}$

\begin{abstract}
Introduction: Anxiety among children has increased in recent years. Culturally adapted questionnaires developed to measure the level of anxiety are the best screening instruments for the general population. This study describes the scientific translation and adaptation of the Spence Children's Anxiety Scale (SCAS) into the Malay language.

Method: The process of scientific translation of this selfreport instrument followed the guidelines of the Task Force for Translation and Cultural Adaptation of the International Society for Pharmacoeconomics and Outcomes Research (ISPOR).

Results: The Malay version and its adaptation for a new cultural context are described.

Conclusion: The Malay version achieved the aims of the original version and its conceptual and operational equivalence. It may be used as the first Malay instrument to measure anxiety among children in research and in clinical and community settings.

Keywords: Anxiety disorders, SCAS-Malay, cross-cultural adaptation, children.
\end{abstract}

\section{Introduction}

The prevalence of anxiety disorders, some of the most common mental health disorders of children, has increased. ${ }^{1}$ International ${ }^{2-4}$ and Malaysian ${ }^{5}$ studies have shown that prevalence during childhood ranges from $6 \%$ to $31.9 \%$. Such disorders may affect a child's social and individual functioning and have a tendency to become chronic. ${ }^{6-8}$ Moreover, they are highly comorbid with other psychiatric disorders and may lead to an increased

\section{Resumo}

Introdução: A ansiedade infantil tem crescido em anos recentes. Questionários culturalmente adaptados e desenvolvidos para medir o nível de ansiedade são os melhores instrumentos de triagem para a população em geral. Este estudo descreve a tradução e adaptação científica da Escala de Ansiedade Infantil de Spence para a língua malásia.

Método: O processo de tradução científica deste instrumento de autorrelato seguiu as orientações da Força-Tarefa para a Tradução e Adaptação Cultural da International Society for Pharmacoeconomics and Outcomes Research (ISPOR).

Resultados: A versão malásia e sua adaptação para um novo contexto cultural são descritas.

Conclusão: A versão malásia atingiu os objetivos da versão original e sua equivalência conceitual e operacional. Poderá ser usada como o primeiro instrumento malásio para medir ansiedade entre crianças em contextos de pesquisa, clínicos ou comunitários.

Descritores: Transtornos de ansiedade, Escala de Ansiedade Infantil de Spence - Malásia, adaptação cultural, crianças.

prevalence of simultaneous and postponed psychological diseases, such as depression and substance abuse, ${ }^{9-12}$ if left untreated or treated inadequately. ${ }^{13,14}$ The use of appropriate tools for the screening, assessment, diagnosis and follow-up of children's anxiety may reduce its side effects. ${ }^{15}$ The best choices are selfreport questionnaires, which are less time-consuming, easy to administer and focused on symptoms based on standard criteria, such as those defined in the Diagnostic and Statistical Manual of Mental Disorders (DSM). ${ }^{16}$

\footnotetext{
${ }^{1}$ Faculty of Education, Universiti Teknologi Malaysia, Skudai, Johor, Malaysia. ${ }^{2}$ Counseling Center, University Technology Malaysia, Skudai, Johor, Malaysia. ${ }^{3}$ Research Center for Modeling in Health, Institute for Futures Studies in Health, Kerman University of Medical Sciences, Kerman, Iran.

Financial support: Ministry of Higher Education (MOHE) and Research Management Centre (RMC), Universiti Teknologi Malaysia (UTM) (institutional grant no. VOT 4F304).

Submitted Sep 04 2014, accepted for publication Nov 25 2014. No conflicts of interest declared concerning the publication of this article.

Suggested citation: Ahmadi A, Mustaffa MS, Haghdoost AA, Khan A, Latif AA. Cross-cultural adaptation of the Spence Children's Anxiety Scale in Malaysia. Trends Psychiatry Psychother. 2015;37(1):37-41. http://dx.doi.org/10.1590/2237-6089-2014-0038
} 
Questionnaires designed to assess anxiety symptoms in children usually originate from those for adults. ${ }^{17} \mathrm{~A}$ few instruments have been adapted to Malay culture to measure anxiety symptoms in adults (e.g., Generalized Anxiety Disorder 7-item [GAD-7] ${ }^{18}$; Spielberger StateTrait Anxiety Inventory [STAI] ${ }^{19}$; Depression Anxiety and Stress Scales [DASS] ${ }^{20}$ ), but there are none for children. In addition, some questionnaires do not include developmental characteristics in the evaluation of childhood anxiety, ${ }^{17}$ and some, such as the StateTrait Anxiety Inventory for Children (STAI-C) and the Revised Children's Manifest Anxiety Scale (RCMAS), do not evaluate the different domains of anxiety. These domains should be diagnosed and differentiated before prescribing adequate medical treatments and psychological interventions and therapies. The Spence Children's Anxiety Scale (SCAS) ${ }^{17}$ was designed to take into account the relevant developmental characteristics of anxiety among children, as well as to assess and specify symptoms of anxiety according to the domains defined in the DSM-IV. ${ }^{15}$ The original SCAS ${ }^{21}$ and crossculturally adapted versions to other languages, such as Dutch, ${ }^{22}$ German, ${ }^{23}$ Hellenic Greek, ${ }^{24}$ Mexican, ${ }^{25}$ Japanese, ${ }^{26}$ Cypriot, $^{27}$ English, Swedish, and Italian, ${ }^{28}$ have achieved acceptable psychometric properties. The aim of this study was to cross-culturally adapt the SCAS (child and parent versions) to the Malay language. There are 118 tools based on the DSM-IV criteria to measure anxiety in children, ${ }^{29}$ but the SCAS is the first to be cross-culturally adapted for use in Malaysia.

\section{Method}

\section{Spence Children's Anxiety Scale - Child Version (SCAS-C)}

The SCAS-C has 44 items, 38 of which are arranged into six domains: separation anxiety; social phobia; obsessive-compulsive problems; generalized anxiety; panic and agoraphobia; and physical injury fears. There are six positive filler items and one open ended question to report any additional fears not considered in the other items. ${ }^{30}$ A Likert-like scale (never, sometimes, often, and always) is used for answering.

\section{Spence Children's Anxiety Scale - Parent Version (SCAS-P)}

Parents are required to answer the SCAS-P items based on their views of their children's symptoms. Thirty-eight items of the parent version follow the same items as in the child version, but there is no positive filler. ${ }^{30}$ The Likert-like scale is the same as the one for the child version. The authors of this study prepared a Malay version of the SCAS, as described here, and evaluated its psychometric properties, as described in another manuscript.

\section{Procedures}

The procedures for translation and adaptation of the SCAS were based on the guidelines for the Translation and Cultural Adaptation group (TCA group) of the International Society for Pharmacoeconomics and Outcomes Research (ISPOR). ${ }^{31}$ The adaptation steps, according to ISPOR, are: a) preparation; b) first forward translation; c) reconciliation; d) back translation; e) back translation review; f) harmonization; g) cognitive debriefing; h) review of cognitive debriefing results and finalization; i) proof reading; and j) final report. ${ }^{32}$

- Preparation phase: The process was initiated by receiving authorization from the original SCAS author for the adaptation of the instrument for use in Malaysia and by then selecting appropriate translators.

- First translation: Two native speakers produced independent translations.

- Reconciliation step: A native Malay speaker synthesized the two forward translations into a single version and reconciled it.

- Back translation: The reconciled version was translated back into the original language for the quality control of the version produced by an independent translator.

- Back translation review: The back translated version was compared with the original by an expert in the field.

- Harmonization: No significant discrepancy needed harmonization into the Malay context when compared with items adopted and translated into other languages.

- Cognitive debriefing: To check understandability, interpretation and cultural relevance of the translated SCAS, child and parent versions were applied to five native Malay children with anxiety, three boys and two girls, and to their parents. Their ages ranged from 8 to 12 years. They were asked to mention any confusing words or statements and comment on what they understood in each item. All participants provided written informed consent. This investigation was approved by the Ethics Committee of the Ministry of Higher Education in medical research.

- Review of cognitive debriefing results and finalization: In step eight, a modified version based 
on the cognitive debriefing results was prepared to make items easier for the target populations to understand.

- Proof reading: Orthographic and syntax changes were made, as needed.

- Final report: The process of cultural adaptation of the SCAS was reported to facilitate transferring the experience acquired during this endeavor to others.

\section{Results}

Table 1 shows the 38 main items of the final version of the SCAS-C-Malay. The SCAS-P items are the same as those in the child version, and so are not mentioned here.

The professionally-checked SCAS-Malay adequately represented each domain's items and the theoretical rationale of the original SCAS. Moreover, the construct would likely be valid in Malaysia.

Table 1 - SCAS original items and corresponding SCAS-Malay items

\begin{tabular}{|c|c|c|}
\hline Domains & Original items & Malay items \\
\hline \multirow[t]{6}{*}{ Separation anxiety } & I would feel afraid of being on my own at home. & Saya akan berasa takut untuk berseorangan di rumah. \\
\hline & I worry about being away from my parents. & Saya bimbang untuk berjauhan daripada ibu bapa. \\
\hline & $\begin{array}{l}\text { I worry that something awful will happen to } \\
\text { someone in my family. }\end{array}$ & $\begin{array}{l}\text { Saya bimbang untuk sesuatu perkara buruk berlaku } \\
\text { terhadap salah seorang ahli keluarga saya. }\end{array}$ \\
\hline & I feel scared if I have to sleep on my own. & Saya berasa takut jika saya terpaksa tidur sendirian. \\
\hline & $\begin{array}{l}\text { I have trouble going to school in the mornings } \\
\text { because I feel nervous or afraid. }\end{array}$ & $\begin{array}{l}\text { Saya mengalami masalah pergi ke sekolah pada waktu pagi } \\
\text { kerana saya berasa gemuruh dan takut. }\end{array}$ \\
\hline & $\begin{array}{l}\text { I would feel scared if I had to stay away from } \\
\text { home overnight. }\end{array}$ & $\begin{array}{l}\text { Saya rasa takut jika saya terpaksa berjauhan dari rumah } \\
\text { saya semalaman. }\end{array}$ \\
\hline \multirow[t]{6}{*}{ Social phobia } & I feel scared when I have to take a test. & Saya berasa takut apabila saya perlu menduduki ujian. \\
\hline & $\begin{array}{l}\text { I feel afraid if I have to use public toilets or } \\
\text { bathrooms. }\end{array}$ & $\begin{array}{l}\text { Saya takut jika saya terpaksa menggunakan tandas awam } \\
\text { atau bilik mandi. }\end{array}$ \\
\hline & $\begin{array}{l}\text { I feel afraid that I will make a fool of myself in } \\
\text { front of people. }\end{array}$ & $\begin{array}{l}\text { Saya berasa takut jika saya akan membodohkan diri saya } \\
\text { sendiri di hadapan orang. }\end{array}$ \\
\hline & I worry that I will do badly at my school work. & $\begin{array}{l}\text { Saya bimbang jika saya melaksanakan tugasan di sekolah } \\
\text { saya dengan teruk. }\end{array}$ \\
\hline & I worry what other people think of me. & $\begin{array}{l}\text { Saya berasa bimbang tentang apa yang orang lain fikir } \\
\text { tentang diri saya. }\end{array}$ \\
\hline & I feel afraid if I have to talk in front of my class. & $\begin{array}{l}\text { Saya rasa takut jika saya terpaksa bercakap di hadapan } \\
\text { kelas. }\end{array}$ \\
\hline \multirow{6}{*}{$\begin{array}{l}\text { Generalized anxiety } \\
\text { disorder }\end{array}$} & I worry about things. & Saya bimbang terhadap banyak perkara. \\
\hline & $\begin{array}{l}\text { When I have a problem, I get a funny feeling in } \\
\text { my stomach. }\end{array}$ & Apabila saya ada masalah, perut saya menjadi tidak selesa. \\
\hline & I feel afraid. & Saya berasa takut. \\
\hline & $\begin{array}{l}\text { When I have a problem, my heart beats really } \\
\text { fast. }\end{array}$ & $\begin{array}{l}\text { Apabila saya menghadapi masalah, jantung saya berdegup } \\
\text { kencang. }\end{array}$ \\
\hline & I worry that something bad will happen to me. & $\begin{array}{l}\text { Saya bimbang jika sesuatu yang buruk akan berlaku } \\
\text { kepada saya. }\end{array}$ \\
\hline & When I have a problem, I feel shaky. & Apabila saya ada masalah, saya rasa menggigil. \\
\hline \multirow[t]{9}{*}{$\begin{array}{l}\text { Panic attack } \\
\text { agoraphobia }\end{array}$} & $\begin{array}{l}\text { I suddenly feel as if I can't breathe when there } \\
\text { is no reason for this. }\end{array}$ & $\begin{array}{l}\text { Saya berasa seolah-olah sesak nafas secara tiba-tiba } \\
\text { walaupun tanpa sebab. }\end{array}$ \\
\hline & $\begin{array}{l}\text { I suddenly start to tremble or shake when there } \\
\text { is no reason for this. }\end{array}$ & $\begin{array}{l}\text { Saya tiba-tiba menjadi gementar atau menggigil tanpa } \\
\text { apa-apa sebab. }\end{array}$ \\
\hline & $\begin{array}{l}\text { All of a sudden I feel really scared for no reason } \\
\text { at all. }\end{array}$ & $\begin{array}{l}\text { Tiba-tiba saya merasa sangat takut tanpa sebarang sebab } \\
\text { sama sekali. }\end{array}$ \\
\hline & $\begin{array}{l}\text { I suddenly become dizzy or faint when there is } \\
\text { no reason for this. }\end{array}$ & $\begin{array}{l}\text { Saya rasa pening atau hendak pengsan secara tiba-tiba } \\
\text { tanpa sebab. }\end{array}$ \\
\hline & $\begin{array}{l}\text { My heart suddenly starts to beat too quickly for } \\
\text { no reason. }\end{array}$ & Jantung saya tiba-tiba berdegup kencang tanpa sebab. \\
\hline & $\begin{array}{l}\text { I worry that I will suddenly get a scared feeling } \\
\text { when there is nothing to be afraid of. }\end{array}$ & $\begin{array}{l}\text { Saya bimbang jika tiba-tiba saya merasa takut tanpa ada } \\
\text { sebarang perkara untuk ditakuti. }\end{array}$ \\
\hline & $\begin{array}{l}\text { I feel scared if I have to travel in the car, or on } \\
\text { a bus or a train. }\end{array}$ & $\begin{array}{l}\text { Saya berasa takut jika saya perlu berjalan menaiki kereta, } \\
\text { bas atau kereta api. }\end{array}$ \\
\hline & $\begin{array}{l}\text { I am afraid of being in crowded places (like } \\
\text { shopping centers, the movies, buses, busy } \\
\text { playgrounds). }\end{array}$ & $\begin{array}{l}\text { Saya takut untuk berada di tempat sesak (contohnya pasar } \\
\text { raya, pawagam, bas, taman permainan yang sesak). }\end{array}$ \\
\hline & $\begin{array}{l}\text { I am afraid of being in small closed places, like } \\
\text { tunnels or small rooms. }\end{array}$ & $\begin{array}{l}\text { Saya takut berada di tempat kecil dan tertutup seperti, } \\
\text { terowong atau bilik kecil. }\end{array}$ \\
\hline
\end{tabular}




\begin{tabular}{|c|c|c|}
\hline \multirow[t]{5}{*}{ Physical injury fears } & I am scared of the dark. & Saya takutkan gelap. \\
\hline & I am scared of dogs. & Saya takut anjing. \\
\hline & I am scared of going to the doctors or dentists. & Saya takut berjumpa dengan doktor atau doktor gigi. \\
\hline & $\begin{array}{l}\text { I am scared of being in high places or lifts } \\
\text { (elevators). }\end{array}$ & $\begin{array}{l}\text { Saya takut untuk saya berada di tempat tinggi atau di } \\
\text { dalam lif. }\end{array}$ \\
\hline & I am scared of insects or spiders. & Saya takut kepada serangga atau labah-labah. \\
\hline \multirow[t]{6}{*}{ Positive fillers } & I am popular amongst other kids my own age. & $\begin{array}{l}\text { Saya dikenali ramai dalam kalangan kawan yang sebaya } \\
\text { dengan saya. }\end{array}$ \\
\hline & I am good at sports. & Saya berkebolehan tinggi dalam bidang sukan. \\
\hline & I am a good person. & Saya seorang budak yang baik. \\
\hline & I feel happy. & Saya berasa gembira. \\
\hline & I like myself. & Saya suka pada diri saya. \\
\hline & I am proud of my school work. & Saya bangga dengan kerja sekolah saya. \\
\hline \multirow[t]{6}{*}{$\begin{array}{l}\text { Obsessive-compulsive } \\
\text { disorders }\end{array}$} & $\begin{array}{l}\text { I have to keep checking that I have done } \\
\text { things right (like the switch is off, or the door is } \\
\text { locked). }\end{array}$ & $\begin{array}{l}\text { Saya perlu sentiasa memastikan saya telah melakukan } \\
\text { perkara dengan betul (seperti telah menutup suis, atau } \\
\text { telah mengunci pintu). }\end{array}$ \\
\hline & $\begin{array}{l}\text { I can't seem to get bad or silly thoughts out of } \\
\text { my head. }\end{array}$ & $\begin{array}{l}\text { Saya berasa tidak berupaya untuk mengeluarkan pemikiran } \\
\text { buruk daripada minda saya. }\end{array}$ \\
\hline & $\begin{array}{l}\text { I have to think of special thoughts to stop bad } \\
\text { things from happening (like numbers or words). }\end{array}$ & $\begin{array}{l}\text { Saya terpaksa memikirkan sesuatu yang istimewa (seperti } \\
\text { nombor dan perkataan) untuk menghentikan sesuatu } \\
\text { perkara yang buruk daripada berlaku. }\end{array}$ \\
\hline & $\begin{array}{l}\text { I have to do some things over and over again } \\
\text { like washing my hands, cleaning or putting } \\
\text { things in a certain order). }\end{array}$ & $\begin{array}{l}\text { Saya perlu melakukan sesuatu perkara secara berulang- } \\
\text { ulang (basuh tangan, mengemas atau menyusun barang di } \\
\text { tempat tertentu). }\end{array}$ \\
\hline & $\begin{array}{l}\text { I get bothered by bad or silly thoughts or } \\
\text { pictures in my mind. }\end{array}$ & $\begin{array}{l}\text { Saya rasa terganggu dengan pemikiran atau gambaran } \\
\text { yang buruk atau bodoh dalam fikiran saya. }\end{array}$ \\
\hline & $\begin{array}{l}\text { I have to do some things in just the right way to } \\
\text { stop bad things happening. }\end{array}$ & $\begin{array}{l}\text { Saya perlu melakukan perkara dengan betul untuk } \\
\text { menghentikan perkara buruk daripada berlaku. }\end{array}$ \\
\hline
\end{tabular}

\section{Discussion}

The final version of the instrument is shown in Table 1. The constructs and symptoms assessed by Malay SCAS, based on the DSM-IV, referred to separation anxiety disorder, social phobia, obsessive-compulsive disorder, panic disorder and agoraphobia, generalized anxiety disorder, and specific phobias, and were the same as those found in the original SCAS. ${ }^{33,34}$ This study described the process of translation and crosscultural adaptation of SCAS into Malay using the method prescribed by the TCA group for cross-cultural adaptation of self-report questionnaires. ${ }^{31}$ One of the advantages of this approach lies in its wide and simple applicability and the detailed guide and methodological rigor for each phase of the adaptation process. This method focuses more on semantic and conceptual equivalences than on detailed linguistic issues, which may lead to low content validity. ${ }^{35}$ To our knowledge, this is the first translation of SCAS to Malay. The Malay version followed the six-domain structure of the original SCAS and included 38 items. Therefore, construct validity of this instrument is equivalent to that of its original English version.
An important step in the translation and adaptation process is the selection of experienced translators fluent in both languages to achieve a fault-free instrument. ${ }^{36}$ In our project, none of the translators except one received financial support for their academic work. Therefore, the process of adaptation took about 4 months, mainly because all experts invited for the evaluation phase were university lecturers. In conclusion, financial issues may impose time constraints on the adaptation process, ${ }^{37}$ a problem that may also be seen in other studies that focused on the adaptation of SCAS to other languages, such as Brazilian Portuguese. ${ }^{15}$

Malaysia has a young population, and the rate of anxiety among the young has increased. ${ }^{38}$ This trend requires preventive interventions and on-time screening and treatment, which may be more scientifically conducted and are easier and faster when using standard instruments. The SCAS-Malay is the first instrument based on the DSM-IV criteria to measure children's anxiety (overall score and six domains of anxiety) in the Malay context. Future cross-cultural studies in community or academic settings may benefit from it. It may also be used in clinical settings to follow up patients or to assess the frequency and severity of anxiety disorders. 


\section{Acknowledgements}

The authors would like to thank the Ministry of Higher Education (MOHE) and the Research Management Centre (RMC), Universiti Teknologi Malaysia (UTM) for financial support of this research (institutional grant no. VOT 4F304).

\section{References}

1. Keeton $\mathrm{CP}$, Kolos $\mathrm{AC}$, Walkup JT. Pediatric generalized anxiety disorder: epidemiology, diagnosis, and management. Paediatr Drugs. 2009;11:171-83.

2. Liu J, Chen X, Lewis G. Childhood internalizing behaviour: analysis and implications. J Psychiatr Ment Health Nurs. 2011;18:884-94.

3. Kessler RC, Berglund $P$, Demler $O$, Jin R, Merikangas KR, Walters EE. Lifetime prevalence and age-of-onset distributions of DSM-IV disorders in the National Comorbidity Survey Replication. Arch Gen Psychiatry. 2005;62:593-602.

4. Merikangas KR, He JP, Burstein M, Swanson SA, Avenevoli $S$, Cui $L$, et al. Lifetime prevalence of mental disorders in US adolescents: results from the National Comorbidity Survey Replication-Adolescent Supplement (NCS-A). J Am Acad Child Adolesc Psychiatry. 2010;49:980-9.

5. Gill JS, Koh OH, Pillai SK. Anxiety disorders among incarcerated drug users [Internet]. Malays ] Psychiatry e]. 2010;19 [cited 2014 Dec 16]. http://www.mjpsychiatry.org/index.php/mjp/ article/view/72

6. Cramer V , Torgersen S, Kringlen E. Quality of life and anxiety disorders: a population study. J Nerv Ment Dis. 2005;193:196-202.

7. Grover RL, Ginsburg GS, Ialongo N. Psychosocial outcomes of anxious first graders: a 7-year follow-up. Depress Anxiety. 2007; 24:410-20.

8. Reuschel LM. Generalized anxiety disorder in children and adolescents: implication for research and practice [Internet]. $2011 \mathrm{Apr}$ [cited 2014 Dec 16]. http://psychology.illinoisstate. edu/cc/Comps/Reuschel\%20-\%20GAD.pdf

9. Ezpeleta L, Keeler G, Erkanli A, Costello EJ, Angold A. Epidemiology of psychiatric disability in childhood and adolescence. J Child Psychol Psychiatry. 2001;42:901-14.

10. Beesdo K, Pine DS, Lieb R, Wittchen HU. Incidence and risk patterns of anxiety and depressive disorders and categorization of generalized anxiety disorder. Arch Gen Psychiatry. 2009;67:47-57.

11. Kim-Cohen J, Caspi A, Moffitt TE, Harrington H, Milne BJ, Poulton R. Prior juvenile diagnoses in adults with mental disorder: developmental follow-back of a prospective-longitudinal cohort. Arch Gen Psychiatry. 2003;60:709-17.

12. Zimmermann P, Wittchen HU, Höfler M, Pfister $H$, Kessler RC, Lieb $R$. Primary anxiety disorders and the development of subsequent alcohol use disorders: a 4-year community study of adolescents and young adults. Psychol Med. 2003;33:1211-22.

13. Emmelkamp P, Wittchen HU. Specific phobias. In: Andrews G, Charney DS, Sirovatka PJ, Regier DA, editors. Stress-induced and fear circuitry disorders: Refining the research agenda for DSM-V. Arlington: American Psychiatric Association; 2009. p. 77-101.

14. Konnopka A, Leichsenring F, Leibing $E$, König HH. Cost-of-illness studies and cost-effectiveness analyses in anxiety disorders: a systematic review. J Affect Disord. 2009;114:14-31.

15. DeSousa DA, Petersen CS, Behs R, Manfro GG, Koller SH. Brazilian Portuguese version of the Spence Children's Anxiety Scale (SCASBrasil). Trends Psychiatry Psychother. 2012;34:147-53.

16. Muris $P$, Merckelbach $H$, Ollendick T, King N, Bogie N. Three traditional and three new childhood anxiety questionnaires: their reliability and validity in a normal adolescent sample. Behav Res Ther. 2002;40:753-72.

17. Spence SH. A measure of anxiety symptoms among children. Behav Res Ther. 1998;36:545-66.

18. Sidik SM, B Arroll, Goodyear-Smith F. Validation of the GAD-7 (Malay version) among women attending a primary care clinic in Malaysia. J Prim Health Care. 2012:4:5-11.

19. Quek KF, Low WY, Razack AH, Loh CS, Chua CB. Reliability and validity of the Spielberger State-Trait Anxiety Inventory (STAI) among urological patients: a Malaysian study. Med J Malaysia. 2004;59:258-67.
20. Ramli M, Ariff MF, Zaini Z. Translation, validation and psychometric properties of Bahasa Malaysia version of the Depression Anxiety and Stress Scales (DASS). ASEAN J Psychiatry. 2007;8:82-9.

21. Orgilés M, Spence SH, Marzo JC, Méndez X, Espada JP. Psychometric properties and factorial structure of the Spence Children's Anxiety Scale (SCAS) in Spanish adolescents. J Pers Assess. 2014;96:95-102.

22. Nauta MH, Scholing A, Rapee RM, Abbott M, Spence SH, Waters A. A parent-report measure of children's anxiety: psychometric properties and comparison with child-report in a clinic and normal sample. Behav Res Ther. 2004;42:813-39.

23. Essau CA, P Muris, Ederer EM. Reliability and validity of the Spence Children's Anxiety Scale and the Screen for Child Anxiety Related emotional disorders in German children. J Behav Ther Exp Psychiatry. 2002;33:1-18.

24. Mellon RC, Moutavelis AG. Structure, developmental course, and correlates of children's anxiety disorder-related behavior in a Hellenic community sample. J Anxiety Disord. 2007;21:1-21.

25. Hernández-Guzmán L, Bermúdez-Ornelas G, Spence SH, González MJ, Martínez-Guerrero JI, Aguilar J, et al. Spanish version of the Spence Children's Anxiety Scale (SCAS). Rev Latinoam Psicol. 2010;42:13-24.

26. Ishikawa $S$, Sato $H$, Sasagawa $S$. Anxiety disorder symptoms in Japanese children and adolescents. J Anxiety Disord. 2009;23:104-11.

27. Essau CA, Anastassiou-Hadjicharalambous $X$, Muñoz LC. Psychometric properties of the Spence Children's Anxiety Scale (SCAS) in Cypriot children and adolescents. Child Psychiatry Hum Dev. 2011;42:557-68.

28. Essau CA, Sasagawa $S$, Anastassiou-Hadjicharalambous $X$, Guzmán BO, Ollendick TH. Psychometric properties of the Spence Child Anxiety Scale with adolescents from five European countries. ] Anxiety Disord. 2011;25:19-27.

29. da Silva WV, de Figueiredo VL. [Childhood anxiety and assessment instruments: a systematic review]. Rev Bras Psiquiatr. 2005;27:329-35.

30. Spence SH. Structure of anxiety symptoms among children: a confirmatory factor-analytic study. J Abnorm Psychol. 1997; 106:280-97.

31. Wild D, Grove A, Martin M, Eremenco S, McElroy S, VerjeeLorenz A, et al. Principles of good practice for the translation and cultural adaptation process for patient $\square$ reported outcomes (PRO) measures: report of the ISPOR Task Force for Translation and Cultural Adaptation. Value Health. 2005;8:94-104.

32. Spanemberg L, Parker G, Caldieraro MA, Vares EA, Costa F, Costa MM, et al. Translation and cross-cultural adaptation of the Temperament \& Personality Questionnaire into Brazilian Portuguese. Trends Psychiatry Psychother. Epub 2014 Aug 12.

33. Manfro GG, Isolan L, Blaya C, Santos L, Silva M. Estudo retrospectivo da associação entre transtorno de pânico em adultos e transtorno de ansiedade na infância. Rev Bras Psiquiatr. 2002;24:26-9.

34. Manfro GG, Isolan L, Blaya C, Maltz S, Heldt E, Pollack MH. Relationship between adult social phobia and childhood anxiety. Rev Bras Psiquiatr. 2003;25:96-9.

35. Baeza FL, Caldieraro MA, Pinheiro DO, Fleck MP. Translation and cross-cultural adaptation into Brazilian Portuguese of the Measure of Parental Style (MOPS)-a self-reported scale-according to the International Society for Pharmacoeconomics and Outcomes Research (ISPOR) recommendations. Rev Bras Psiquiatr. 2010;32:159-63.

36. Wang WL, Lee HL, Fetzer SJ. Challenges and strategies of instrument translation. West J Nurs Res. 2006;28:310-21.

37. Gjersing L, Caplehorn JR, Clausen T. Cross-cultural adaptation of research instruments: language, setting, time and statistical considerations. BMC Med Res Methodol. 2010;10:13.

38. Krishnaswamy $S$, Subramaniam $K$, Jemain AZ, Low WY, Ramachandran $\mathrm{P}$, Indran $\mathrm{T}$, et al. Common mental disorders in Malaysia: Malaysian mental health survey, 2003-2005. Asia Pac Psychiatry. 2012;4:201-9.

\section{Correspondence:}

Mohamed Sharif Mustaffa

Counseling Center, University Technology Malaysia

81300 - Skudai, Johor, Malaysia

Tel. : 0060197386428

E-mail: p-sarif@utm.my 